\title{
PENGEMBANGAN INSTRUMEN PEMBELAJARAN DARING UNTUK MATERI HUKUM PADA MATA PELAJARAN PPKn DI MGMP KABUPATEN KARANGANYAR
}

\author{
Rima Vien Permata ${ }^{1}$, Triyanto ${ }^{2}$, Hassan Suryono ${ }^{3}$, Triana Rejekiningsih ${ }^{4}$, \\ Dewi Gunawati ${ }^{5}$, Yudi Ariana ${ }^{6}$, Widya Noventari ${ }^{7}$ \\ 1,2,3,4,5,6,7 Universitas Sebelas Maret \\ ${ }^{1}$ rimavien@staff.uns.ac.id, ${ }^{2}$ try_uns@yahoo.com, ${ }^{3}$ hassansuryono@yahoo.com, \\ ${ }^{4}$ triana_rizq@staff.uns.ac.id, ${ }^{5}$ dewigunawatiuns@yahoo, ${ }^{6}$ y_ariana@yahoo.com, \\ ${ }^{7}$ widyanoventari@staff.uns.ac.id.
}

\begin{abstract}
Community service as one part of the pillars of Tri Dharma college is carried out as a tangible manifestation of the role of collage in meeting community criticisms. Legal and Citizenship Research Group, FKIP, UNS in collaboration with MGMP PPKn SMA/SMK, Karanganyar Regency carried out Community Service activities aimed at PPKn SMA/SMK teachers as an effort to increase understanding and improve the quality of Civics learning in the development of online learning instruments, especially on material law. This community service activity aims to: 1) improve the mastery and understanding of Civics teachers on legal material, 2) increase knowledge and ability in compiling online learning instruments, 3) improve the ability of teachers in developing learning media in the online learning process. While the benefits of this activity are the maintenance of the continuity of the Tri Dharma of Higher Education functions, namely the functions of education, research, and community service. The method used is in the form of training (workshop) by providing understanding and prioritizing increasing teacher knowledge regarding strengthening legal material in Civics subjects and online learning instruments. This activity showed very satisfactory results. The teachers have very high enthusiasm to take part in this training and the ability to make online learning instruments and the development of learning media has increased.
\end{abstract}

Keywords: instrument, online learning, law materials, civics education.

\section{PENDAHULUAN}

Masuknya wabah pandemi Covid-19 terjadi hampir di seluruh dunia, tidak hanya mengguncang dunia kesehatan tetapi hampir disemua bidang kehiduap sosial masyarakat, salah satunya di dunia pendidikan. Dalam dunia pendidikan ada 4 hal perubahan akibat terjadinya wabah pandemi Covid-19, diantaranya; (1) terjadinya konektifitas di dalam dunia pendidikan yang ada di seluruh belahan dunia, sehingga semakin saling terhubung, (2) pendefinisian ulang peran dari pendidik, (3) memberikan pengajaran betapa pentingnya sebuah keterampilan hidup di masa yang akan datang, (4) peran teknologi dalam dunia pendidikan semakin terbuka luas (Luthra \& Mackenzi, 2020).

Senada dengan pendapat tersebut, Tam dan El Azar (2020) juga mengungkapkan bahwa pandemi Covid-19 mampu menciptakan perubahan mendasar di dalam pendidikan global, diantaranya; (1) cara mendidik jutaan orang berubah, (2) inovasi pendidikan sebagai inovasi baru, (3) kesenajangan digital dalam proses pembelajaran baru yakni pembelajaran dalam jaringan (daring) menyebabkan pergeseran baru dalam pendekatan di dunia pendidikan yang mestinya akan semakin memperluas kesenjangan tersebut.

Luthra \& Mackenzi (2020) maupun Tam dan El Azar (2020) menunjukkan bahwa Covid-19 menbuat percepatan transformasi pendidikan dengan terpaksa, karena perubahan tersebut dianggap sesuatu yang niscaya sebelumnya untuk dilakukan karenadalam penerapanya sebelum masa pandemi terjadi begitu lambat. Tetapi karena wabah pandemi Covid-19 ini perubahan yang awalnya dianggap tidak mungkin terjadi justru terjadi begitu pesat. Dalam waktu yang cukup singkat dunia mengubah pola 
pembelajaran konvensional seperti tatap muka di sekolah menjadi pembelajaran jarak jauh (PJJ) yang sangat mengandalkan teknologi (Luthra \& Mackenzi, 2020), (Tam dan El Azar, 2020).

UNICEF, WHO dan IFRC dalam Covid-19 Prevention and Control in Schools (Maret, 2020) menyatakan bahwa situasi persebaran wabah Covid-19 sangat tinggi dan cepat, oleh karenanya dengan sangat terpaksa sekolah harus ditutup dan proses pembelajaran dilakukan secara online melalui berbagai platform atau media. Hasil data UNNESCO (2020) didapati hampir 1,5 miliar siswa dan 63 juta guru mulai dari tingkat dasar hingga menengah di 191 negara terkena dampat pandemi ini, yang merupakan kejadian tak pernah terjadi sebelumnya. Hal ini membuat semua element lembaga pendidikan memutar haluan untuk merubah teknik belajar yang awalnya dilakukan secara konvensional atau tatap muka menjadi pembelajaran daring. Transformasi digital adalah langkah terbaik yang harus dilakukan untuk mencegak penyebaran virus Covid-19. Dikarenakan, hak para siswa untuk mendapatkan pendidikan tetap menjadi prioritas tanpa mengabaikan kesehatan dan keselamatan jiwa (UNICEF, IRC, \& WHO, 2020).

Negara-negara di dunia, mengutip Zhong (2020) dalam artikelnya di nytimes.com "The Coronavirus Exposes Education's Digital Divide", dalam menghadapi wabah pandemi covid-19 menyebabkan sekolah melakukan kegiatan pembelajaran secara daring. Di China, misalnya banyak orang tua yang tidak mampu membeli perangkat digital untuk mendukung pembelajaran daring juga adanya keterbatasan sinyal di beberapa wilayah perdesaan. Biaya internet juga sangat mahal di luar kota besar. Yang menarik China memiliki mantra sakti: stop classes but don't stop learning.

Di Indonesia, pada 24 Maret 2020 Menteri Pendidikan dan Kebudayaan Republik Indonesia mengeluarkan Surat Edaran Nomor 4 Tahun 2020 tentang Pelaksanaan Kebijakan Pendidikan Dalam Masa Darurat Penyebaran Covid yang menjelaskan bahwa proses belajar pembelajaran dilakukan di rumah melalui pembelajaran jarak jauh melalui daring; belajar dari rumah (BDR) yang kemudian disebut juga belajar online. Ada beberapa poin penting yang terlihat dari kebijakan tersebut; (1) pembelajaran daring/jarak jauh memberi pengalaman belajar yang bermakna, tanpa terbebani dengan tuntutan menuntaskan seluruh capaian kurikulum sebagai kenaikan kelas maupun kelulusan. (2) mampu difokuskan pada pendidikan kecakapan hidup, antara lain mengenai pandemi Covid-19. (3) aktivitas dan tugas pembelajaran dapat bervariasi antar siswa, sesuai minat dan kondisi masing-masing, termasuk mempertimbangkan kesenjangan akses/fasilitas belajar di rumah (Kemdikbud, 2020).

Guru sebagai pendidik di sekolah menghadapi banyak kendala untuk menerapkan kebijakan pembelajaran daring tersebut. Beberapa kendala yang dihadapi oleh guru disamping harus membuat instrument pembelajaran yang disesuaikan, guru dituntut juga untuk aktif dalam memantau perkembangan peserta didik. Dalam kapasitas ini, guru harus mampu menyiapkan kelengkapana isntrumen pembelajaran daring agar dapat terorganisasi dengan baik sehingga dalam melaksanakan pembelajaran, penilaiian dan hal lainya sesuai dengan istrumen yang sudah dibuatnya sendiri seperti sebelum masa pandemi.

Namun berdasarkan hasil pengamatan dan diskusi tim pengabdi dengan guru saat melakukan program magang kependidikan di Kabupaten Karanganyar tahun 2020, guru Pendidikan Pancasila dan Kewarganegaraan (PPKn) mengalami ketidaksiapan instrumen pembelajaran khususnya pada materi hukum sehingga hal ini menjadi kendala guru dalam proses pembelajaran daring. Berdasarkan permasalahan yang dihadapi guru mata PPKn tersebut, maka perlu pembekalan untuk pengembangan bagi guru mata pelajaran PPKn SMA/SMK di Kabupaten Karanganyar dalam menyiapkan instrumen pembelajaran 
khususnya pada materi hukum untuk kelancaran proses pembelajaran dan pencapian tujuan pembelajaran PPKn.

Berawal dari permasalahan yang sedang dialami oleh guru saat ini maka secara khusus Pengabdian pada Masyarakat ini bertujuan untuk memberi pembekalan untuk pengembangan bagi guru mata pelajaran Pendidikan Pancasila dan Kewarganegaraan (PPKn) SMA/SMK di Kabupaten Karanganyar dalam menyiapkan instrumen pembelajaran khususnya pada materi hukum untuk kelancaran proses pembelajaran dan pencapian tujuan pembelajaran PPKn. Selain itu kegiatan ini juga bertujuan untuk penguatan kapasitas guru PPKn menuju guru profesional.

\section{METODE}

Upaya meningkatkan kesiapan guru dalam menyiapkan instrumen pembelajaran atau perangkat pembelajaran khususnya tentang materi hukum dilaksanakan dalam forum pelatihan dan pendampingan. Alur kegiatan Pengabdian kepada Masyarakat bagi mitra guru dalam Musyawarah Guru Mata Pelajaran (MGMP) PPKn SMA Kabupaten Karanganyar dapat dilihat pada gambar 1.

\begin{tabular}{|c|c|c|}
\hline \multicolumn{3}{|c|}{ Perencanaan } \\
\hline Analisis Situasi & Menyusun Proposal & Menyusun Kegiatan Teknis \\
\hline \multicolumn{2}{|c|}{ Pelaksanaan } \\
\hline $\begin{array}{c}\text { Memberi pelatihan dan pendampingan tentang instrumen pembelajaran daring } \\
\text { khususnya pada materi hukum mata pelajaran PPKn }\end{array}$ \\
\hline
\end{tabular}

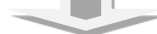

\begin{tabular}{|c|}
\hline Evaluasi dan Pelaporan \\
\hline Menyusun laporan akhir \\
\hline
\end{tabular}

Gambar 1.Tahapan Kegiatan Pengabdian kepada Masyarakat

Rangkaian kegiatan Pengabdian kepada Masyarakat diuraikan sebagai berikut:

1. Tahap Perencanaan

Tahap ini dimulai dengan menganalisis permasalahan mitra kemudian menyusun proposal untuk dievaluasi kelayakan dan pendanaan. Pada tahap ini terdiri dari aktivitas :

1) Penyiapan bahan administrasi

2) Melakukan koordinasi dengan MGMP PPKn SMA/SMK Kabupaten Karanganyar

3) Menyiapkan materi pelatihan dan sarana prasarana pendukung pelatihan

4) Menyiapkan jadwal pelatihan sesuai dengan perencanaan kegiatan

5) Setelah proposal disetujui untuk didanai, disusun Rencana Kerja Operasional (RKO)

2. Tahap Pelaksanaan

Tahap pelaksanaan kegiatan pengabdian ini adalah melakukan pelatihan bagi guru yang tergabung dalam MGMP PPKn SMA/SMKKabupaten Karanganyar. Metode yang digunakan dalam pelatihan ini meliputi pemberian materi dan melakukan praktik mengenai instrumen pembelajaran daring khususnya pada materi hukum mata pelajaran PPKn. Pada tahap ini terdiri dari kegiatan sebagai berikut:

1) Melakukan pelatihan mengenai instrumen pembelajaran daring khususnya pada materi hukum mata pelajaran PPKn, diawali dari materi konsep pembelajaran 
daring, penyampaian materi sistem dan badan peradilan di Indonesia sebagai contoh dan pembuatan media pembelajaran daring.

2) Diskusi mengenai pemahaman materi

3) Praktik langsung bagi peserta dan pendampingan menyiapkan media pembelajaran daring

\section{HASIL KARYA UTAMA DAN PEMBAHASAN}

Tahapan pelaksanaan kegiatan pengabdian ini dilakukan dengan pelatihan yang diikuti 30 guru yang tergabung MGMP PPKn SMA/SMK Kabupaten Karanganyar. Pada tahap persiapan, Tim Research Group Hukum dan Kewarganegaraan (RG Hukum \& Kewarganegaraan) melakukan rapat koordinasi internal dengan agenda mempersiapkan bahan administrasi guna kegiatan pengabdian kepada masyarakat yang akan dilaksanakan di MGMP PPKn SMA/SMK Kabupaten Karanganyar. Setelah mempersiapkan bahan administrasi, tahap selanjutnya yakni melakukan koordinasi dengan MGMP PPKn SMA/SMK Kabupaten Karanganyar terkait dengan penjadwalan dan tempat pelaksanaan kegiatan pengabdian yang kemudian disepakati dilaksanakan secara luring (luar jaringan) di SMA Muhammadiyah 1 Karanganyar. Pelaksanaan kegiatan pengabdian yang dilaksanakan secara luring ini membutuhkan persiapan yang cukup matang khususnya terkait dengan standar protokol kesehatan.

Dalam kegiatan persiapan materi pelatihan dan sarana prasarana pendukung pelatihan, tim RG Hukum dan Kewarganegaraan menggunakan hasil penelitian awal yang berjudul "Identifikasi Kesulitan Guru PPKn dalam Menerapkan Pembelajaran Daring untuk Materi Hukum" di MGMP PPKn SMA/SMK Kabupaten Karanganyar. Sehingga dari hasil penelitian tersebut akan dihasilkan kajian bahan materi dan sarana prasarana yang sesuai dengan kebutuhan guru selama masa pembelajaran daring. Setelah disepakati terkait teknis pelaksanaan kegiatan, persiapan materi dan sarana prasarana pendukung, maka metode yang digunakan dalam pelatihan ini meliputi:

a. Pemaparan Materi

Pemaparan materi pertama tentang konsep pembelajaran daring. Pada materi ini disampaikan tentang pentingnya guru PPKn yang terampil dalam meresponi tatanan kehidupan baru di bidang pendidikan akibat pandemi virus corona. Guru PPKn harus mampu merencanakan pembelajaran daring, mulai dari menentukan strategi pembelajaran, menyiapkan media pembelajaran, menentukan setting, dan instrumen asesmennya.

Sejalan dengan pemahhaman tersebut menurut Marpanaji dkk (2018) dalam suatu proses kegiatan belajar mengajar pada prinsipnya adalah proses komunikasi antara guru dan siswa, yaitu penyampaian pesan (dalam hal ini materi pembelajaran) dari guru kepada siswa. Salah satu komponen proses komunikasi secara umum adalah media komunikasi yang berfungsi sebagai saluran dalam menyampaikan pesan. Media komunikasi dalam proses pembelajaran sering disebut sebagai media pembelajaran. Fungsi dari media pembelajaran adalah sebagai salah satu sarana dalam mencapai tujuan pembelajaran. Sehingga, apabila media pembelajaran dipilih dengan tepat, maka akan semakin efektif pula proses pembelajarannya. Jadi, memilih yang tepat media akan sangat mempengaruhi keberhasilan proses pembelajaran.

Disinilah pentingnya sebuah perencanaan strategi pembelajaran khususnya pemanfaatan media pembelajaran dalam pembelajaran daring di masa pandemi ini. Selama kegiatan pendampingan dan pelatihan ini didapati para guru sangat antusias untuk menyimak materi dan berdiskusi secara mendalam. Hal ini dikarenakan, dari hasil refleksi selama proses pembelajaran daring masih belum memaksimalkan 
penggunaan media salah satunya yakni menggunakan media pembelajaran berupa audio visual yang dirasa cukup efektif dan mudah digunakan oleh guru maupun peserta didik dalam rangka meningkatkan motivasi belajar dan pemahaman peserta didik terhadap subtansi materi yang disajikan. Berikut adalah contoh materi konsep pembelajaran daring yang diberikan dalam pendampingan dan pelatihan.

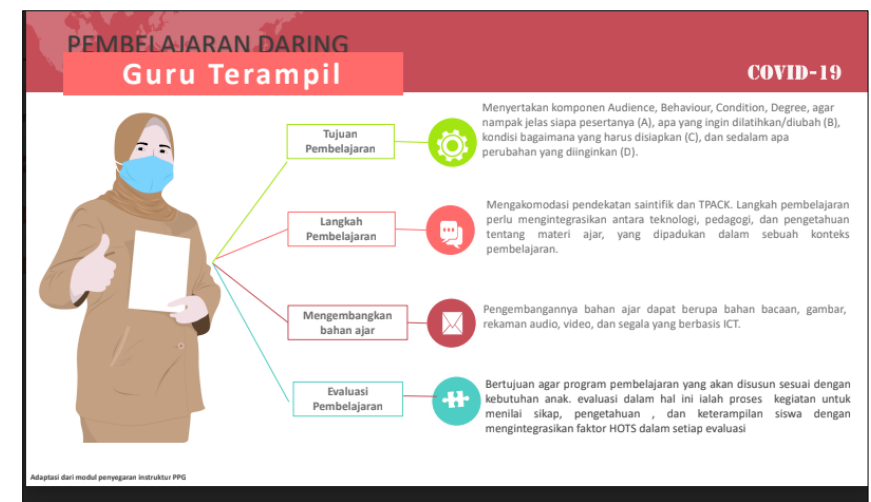

Gambar 2. Contoh materi konsep pembelajaran daring

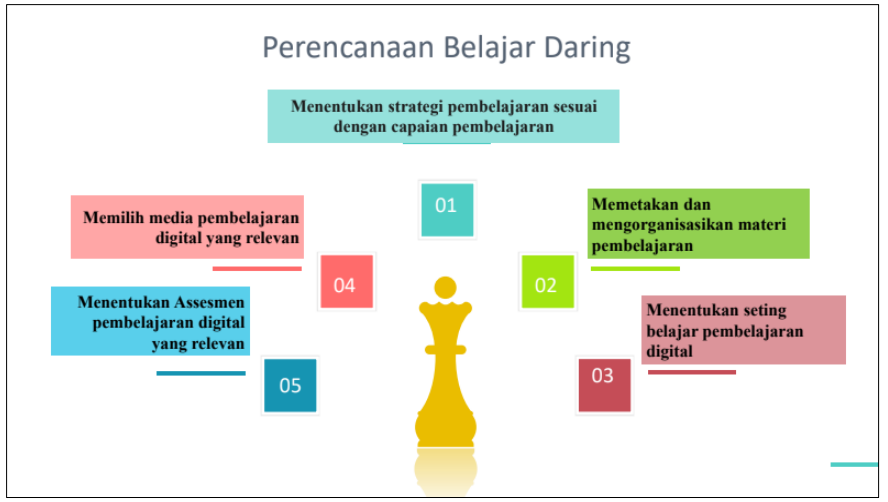

Gambar 3. Contoh materi konsep pembelajaran daring

Penting bagi seorang pendidik untuk memahami dan mengelola pembelajaran daring. Senada dengan pendapat Florence Martin dan Anthony Karl Betrus (2019) bahwa pembelajaran online atau lebih kita kenal saat ini dengan daring pada dasarnya telah meningkat dalam dekade terakhir. Hal ini dapat dilihat dari lebih dari enam juta siswa di Amerika Serikat mengambil setidaknya satu kursus online dalam satu semester. Sementara seluruh kursus dapat ditawarkan secara online, ada berbagai model di mana bagian dari kursus dapat ditawarkan secara online (campuran/hibrid) dan berbagai model online lainya (sinkron dan asinkron). Pembelajaran daring saat ini bukan hanya menjadi sebuah hal yang baru lagi, tetapi sudah menjadi norma baru dalam dunia pendidikan. Meskipun dalam proses adaptasinya ditengah masa pandemi ini semua dituntut mampu menguasai dalam waktu yang cukup singkat.

Beberapa tantangan pembelajaran daring yang sering dikeluhkan oleh para guru selama pelaksaan pendampingan dan pelatihan ini yakni kurangnya perangkat seperti laptop, komputer, smart phone dan jaringan internet, serta adaptasi dengan berbagai platform online serta media pembelajaran pendukung. Dibalik beberapa tantangan yang dihadapi, pembelajaran dari memiliki bebrapa manfaat, diantaranya: 1) membangun interaksi pembelajaran, 2) memungkinkan terjadi interaksi pembelajaran dimana saja dan kapan saja, 3) menjangkau peserta didik dalam cakupan yang lebih luas, 4) mempermudah dalam dokumentasi digital materi pembelajaran, dan membuat 
tidak merasa bosan, semakin tertarik, dan aktif dalam mengikuti pembelajaran (Suhartono, 2020). Selain itu, pembelajaran daring juga menuntut peserta didik untuk belatih belajar secara mandiri sehingga meningkatkan rasa disiplin, tanggung jawab, dan merangsang nalar kritis peserta didik.

Pemaparan materi kedua tentang sistem dan badan peradilan di Indonesia. Materi ini disampaikan untuk memberi contoh kajian hukum pada mata pelajaran PPKn. Secara harfiah, sistem diartikan sebagai sebuah kesatuan yang bersifat menyeluruh yang terdiri dari beberapa bagian yang saling berhubungan. Adapun peradilan merupakan segala sesuatu yang berhubungan satu sama lain. Keduanya membentuk sinergi di bidang hukum secara menyeluruh di suatu negara. Dalam prosesnya inilah diperlukan suatu peradilan. Peradilan diartikan sebagai pelaksanaan hukum dalam hal konkrit, berhubungan dengan tugas negara menegakkan hukum dan keadilan, adanya tuntutan hak, fungsi mana dijalankan oleh suatu badan yang berdiri sendiri dan diadakan oleh negara serta bebas dari pengaruh apa atau siapapun dengan cara memberikan putusan yang bersifat mengikat dan bertujuan mencegah "eigenrichting".

Berbeda dengan Peradilan, konteks Pengadilan (rechtsbank) berarti berbicara dari segi badan yang melakukan peradilan, yaitu badan manakah yang berwenang memeriksa dan memutus sengketa hukum dan pelanggaran hukum/undang-undang. Di Indonesia, penyelenggaraan kegiatan peradilan dilakukan oleh Mahkamah Agung dan badan peradilan yang ada di bawahnya, dan oleh sebuah Mahkamah Konstitusi. Empat lingkungan peradilan itu terbagi dalam dua jenis, yaitu General Jurisdiction meliputi lingkungan Peradilan Umum dan Special Jurisdiction yang terdiri atas Peradilan Agama, Peradilan Militer, dan Peradilan Tata Usaha Negara. Klasifikasi badan peradilannya sebagai berikut:

1. Peradilan Umum, meliputi sengketa perdata dan pidana. Dasar peraturan terkait Peradilan Umum dapat dilihat melalui Undang-Undang No. 49 Tahun 2009 jo. Undang-Undang No. 8 Tahun 2004 jo. Undang-Undang No. 2 Tahun 1986. Sengketa perdata dan pidana misalnya seperti, pencurian, pembunuhan, dan sengketa tanah.

2. Peradilan Agama, adalah peradilan khusus bagi orang-orang yang beragama Islam. Peradilan ini bertugas memeriksa, memutus, dan menyelesaikan perkara di bidang perkahwinan, perceraian, waris, wasiat, hibah, wakaf dan sadaqoh, berdasarkan hukum Islam. Peraturan yang mengatur tentang Peradilan Agama terdapat dalam Undang-Undang No. 50 Tahun 2009 jo. Undang-Undang No. 7 Tahun 1989.

3. Peradilan Tata Usaha Negara, meliputi sengketa antara warga negara dan pejabat tata usaha negara. Objek yang disengketakan yaitu keputusan tata usaha negara yang dikeluarkan oleh pejabat tata usaha negara. Warga negara yang merasa dirugikan atau terganggu hak-hak pribadinya atas adanya suatu peraturan/keputusan yang dikeluarkan pejabat berwenang, maka dapat mengajukan pembelaan hak melalui Peradilan Tata Usaha Negara. Peradilan Tata Usaha Negara diatur dalam Undang-Undang No. 51 Tahun 2009 jo. UndangUndang No. 5 Tahun 1986.

4. Peradilan Militer, meliputi kejahatan atau pelanggaran yang terjadi di lingkup militer. Landasan hukumnya terdapat dalam Undang-Undang No. 31 Tahun 1997. 
Berikut adalah contoh materi sistem dan badan peradilan di Indonesia.

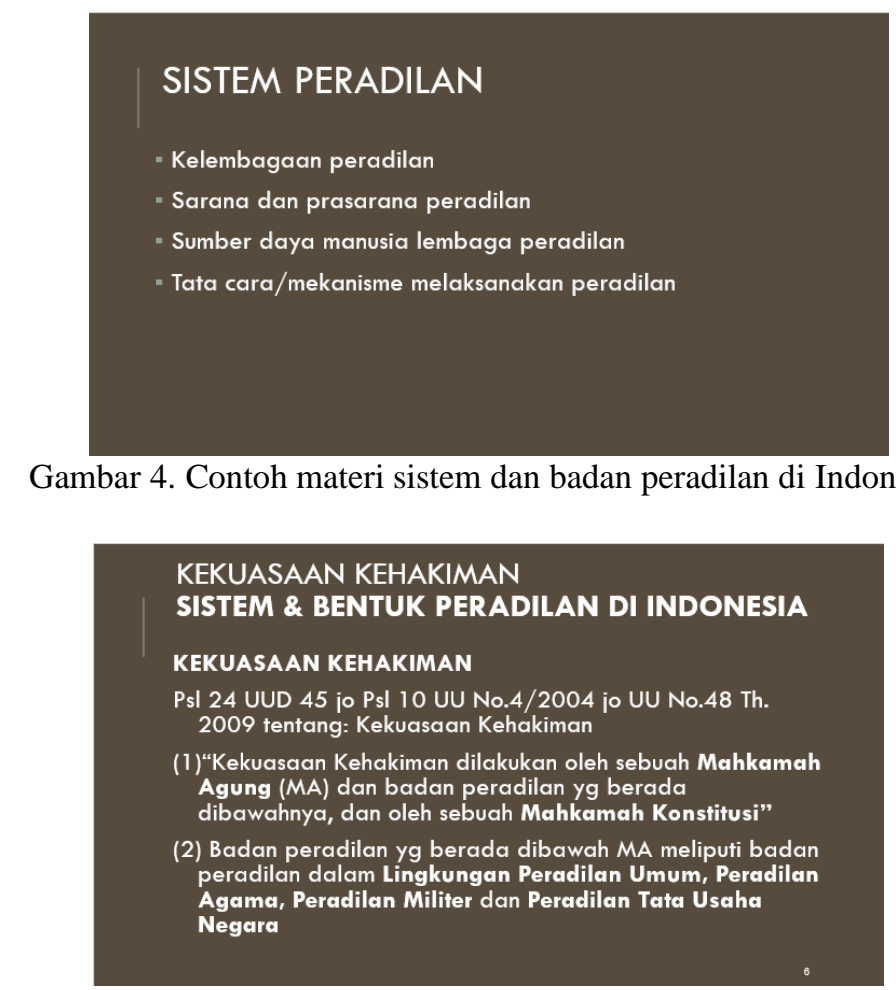

Gambar 5. Contoh materi sistem dan badan peradilan di Indonesia

Materi selanjutnya yakni tutorial pembuatan media pembelajaran sebagai salah satu inovasi guru dalam mengembangkan materi pembelajaran yang lebih menarik. Tutorial pembuatan media pembelajaran yang dimaksud yakni pembuatan video explainer dengan menggunakan Microsoft Power Point (PPT). Pemilihan PPT sebagai media dalam pembuatan video explainer ini mempertimbangkan kemudahan PPT dalam penggunaanya yang tentunya guru-guru juga sudah sangat piawai. Tutorial pembuatan media pembelajaran video explainer ini juga diupload dalam youtube untuk memudahkan guru-guru menonton ulang penjelasan tutorial tersebut. Pembuatan video explainer menjadi salah satu media penyalur pesan yang dirasa cukup efektif karena memberikan ilusi dan fantasi dari gambar bergerak. Berikut contoh video tutorial pembuatan video explainer menggunakan PPT yang dapat diakses di youtube.

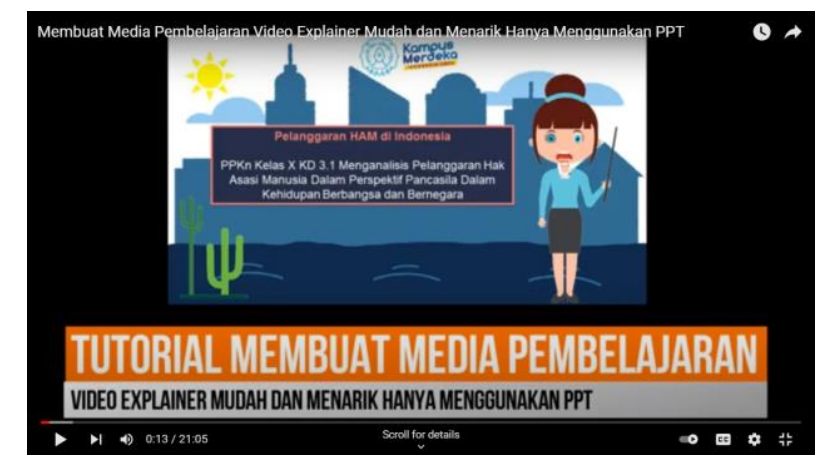

Gambar 6. Video Tutorial Pembuatan video Explainer menggunakan PPT 


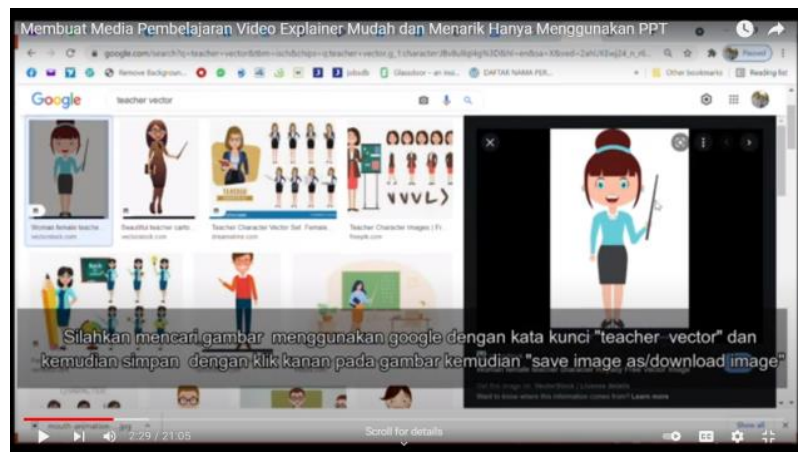

Gambar 7. Video Tutorial Pembuatan video Explainer menggunakan PPT

Melalui pendampingan dan pelatihan pembuatan media pembelajaran ini maka guru akan semakin terampil dalam hal menginovasi media dukung untuk materi pembelajaranya. Pemilihan media pembelajaran yang tepat akan mendukung capaian pembelajaran lebih maksimal. Menurut Donatella Persico (2016) memilih media mana yang akan digunakan dalam proses pembelajaran adalah fase penting dari desain pendidikan. Guru, pelatih, dan perancang materi pembelajaran semuanya menghadapi masalah dalam mengidentifikasi media yang paling cocok untuk menyampaikan pesan, untuk memfasilitasi pemahaman konsep, untuk memperoleh dan mengkonsolidasikan berbagai jenis keterampilan. Dari pernyataan tersebut dapat disimpulkan bahwa guru sendiri masih mengalami kendala dalam memilih dan memilah media pembelajarannya.

Memilih media dalam upaya mendukung kelancaran proses pembelajaran merupakan suatu tugas yang sangat komplek. Guru diharapkan mampu mempertimbangkan banyaknya media yang tersedia, variasi pebelajar, dan tujuan yang ditetapkan. Beberapa hal yang bisa dilakukan untuk memilih media pembelajaran yakni dilihat dari setting pembelajarannya, misalnya: kelompok besar, kelompok kecil, atau pembelajaran mandiri. Membagi variabel pembelajar, misalnya: pembaca, non pembaca, auditif, dan hakikat tujauan, misalnya: kognitif, afektif, psikomotor, atau interpersonal. Selain itu juga perlu dipertimbangkan kemampuan penyajian tiap bentuk media, misalnya: visual diam, visual gerak, kata-kata tercetak, atau kata terucap (Wahyudi, 2019). Oleh karena itu, proses pendampingan dan pelatihan terkait pembuatan media explainer menggunakan PPT ini menjadi salah satu inovasi yang bisa dilakukan oleh para guru untuk membuat media pembelajaran dalam bentuk audio visual.

b. Diskusi dan praktik

Setelah pemaparan materi, dilanjutkan dengan diskusi materi yang telah disampaikan melalui tanya jawab. Tahap ini diakhiri dengan praktik membuat media pembelajaran daring. Dokumentasi pada tahap ini sebagai berikut.
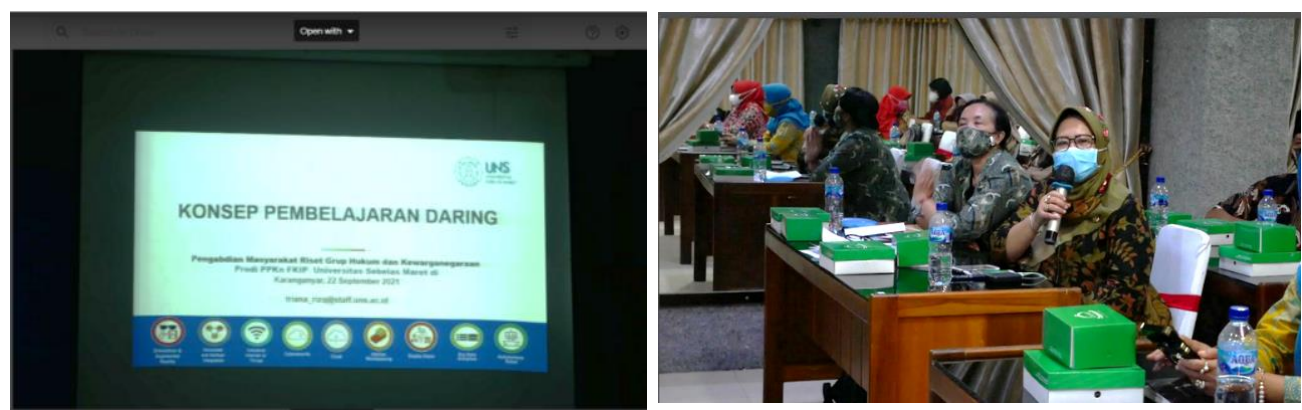

Gambar 7. Kegiatan diskusi dan praktik 

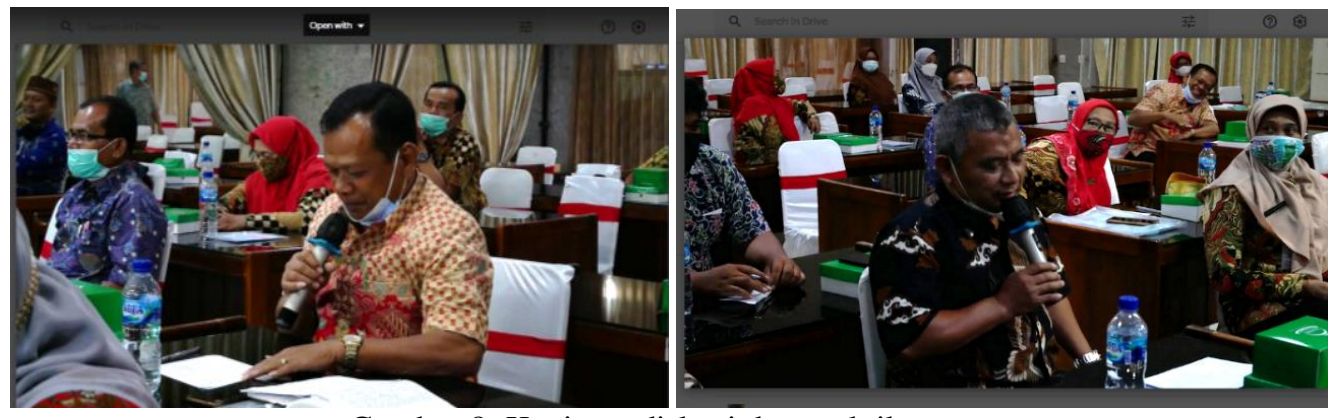

Gambar 8. Kegiatan diskusi dan praktik

Tahap evaluasi dilaksanakan setelah selesainya tiap bentuk kegiatan dilaksanakan dan evaluasi secara keseluruhan kegiatan Pengabdian pada Masyarakat ini telah selesai dilaksanakan dengan teknik wawancara dan observasi. Keberlanjutan kegiatan Pengabdian kepada Masyarakat akan dilakukan dengan cara menjadikan MGMP PPKn SMA di Kabupaten Karanganyar sebagai kelompok binaan.

\section{KESIMPULAN}

Pelaksanaan kegiatan Pengabdian kepada Masyarakat yang dilakukan oleh Tim RG Hukum dan Kewarganegaraan berjalan dengan baik sesuai dengan rencana dan mendapat respon positif dari peserta. Hal ini terlihat dari antusiasme peserta ketika mengikuti pemaparan materi, pelatihan serta pendampingan. Melalui kegiatan pelatihan dan pendampingan ini guru mampu pengembangkan subtansi materi mata pelajaran PPKn khususnya pada materi hukum dengan lebih baik. Selain itu guru juga mampu menyusun instrument pembelajaran daring untuk mendukung kelancaran proses pembelajaran dan tercapainya tujuan pembelajaran PPKn. Berdasarkan hasil evaluasi atas kegiatan, para guru harus terus memperkuat kapasitas diri sebagai seorang guru PPKn menuju guru professional. Sedangkan bagi RG Hukum dan Kewarganegaraan dari hasil evaluasi disarankan agar kegiatan serupa dilaksanakan secara berkala dan diselenggarakan berdasarkan permasalahan dan kebutuhan bersama.

\section{UCAPAN TERIMA KASIH}

Ucapan terima kasih dari Tim Pengabdian kepada Masyarakat RG Hukum dan Kewarganegaraan FKIP Universitas Sebelas Maret kepada LPPM Universitas Sebelas Maret Surakarta yang telah menfasilitasi kegiatan ini dan Musyawarah Guru Mata Pelajaran (MGMP) PPKn SMA/SMK Kabupaten Karanganyar sebagai mitra dalam kegiatan ini.

\section{DAFTAR PUSTAKA}

Luthra, Poornima \& Mackenzie, Sandy. 2020. 4 Ways Covid-19 Education Future Generations. Sumber: https://www.weforum.org/agenda/2020/03/4-wayscovid-19-educationfuture-generations/.

Kementerian Pendidikan dan Kebudayaan. Surat Edaran Kemdikbud Nomor 4 Tahun 2020 tentang Pelaksanaan Pendidikan Dalam Masa Darurat Coronavirus Disease (Covid-19).Jakarta:Kemendikbud.

https://www.kemdikbud.go.id/main/blog/2020/03/mendikbudterbitkan-setentang-pelaksanaanpendidikan-dalam-masa-daruratcovid19. 
Marpanaji, E, Mahali , MI, Putra, R A S. 2018. Survey on How Select and Develop learning Media Conducted by Teacher professional Education Participants. ICELINVO IOP Conf. Series: Journal od Physics: conf. Series 1140 (2018) 012014.

Martin, Florence \& Betrus, Anthony Karl. 2019. Digital Media for learning: Theories, processes, and Solutions. Springer nature Switzerland AG.

Persico, Donatella. 2016. Media Selection from the teacher's Point of View. n A. Cartelli (ed.), Teaching in the Knowledge Society: New Skills and Instruments for Teachers (pp.286-301). Hershey, PA: IGI Global

Tam, Gloria \& El-Azar, Diana. 2020. 3 ways the coronavirus pandemic could reshape education. Sumber: https://www.weforum.org/agenda/2020/03/3-wayscoronavirus- isreshaping-education-and-whatchanges-might-be-here-to-stay/.

Suhartono. 2020. Analisis Pengaruh Pembelajaran Daring Terhadap Kemampuan Literasi Mahasiswa. Jurnal Ilmiah Innovative.

UNICEF, IRC, \& WHO. 2020. Key Messages and Actions for COVID19 Prevention and Control in Schools. Sumber :

https://www.who.int/docs/defaultsource/coronaviruse/key-messagesandactions-for-covid-19prevention-and-control-inschoolsmarch2020.pdf?sfvrsn=baf81d52_4.

Wahyudi, nanang Gesang. 2019. Desain Pesan Pembelajaran dalam Meningkatkan Mutu Pembelajaran Di Era Digital. Jurnal Evaluasi: http://e-journal.staimaalhikam.ac.id/index.php/evaluasi.

Zhong, Raymond. 2020. The Coronavirus Exposes Education's Digital Divide. Sumber: https://www.nytimes.com/2020/03/17/technology/chinaschoolscoronavirus.html. 